\title{
Los acervos de documentos musicales. ¿Libros raros, libros especiales?
}

\author{
Artemisa M. Reyes Gallegos *
}

Artículo recibido:

29 de julio de 2014.

Artículo aceptado:

2 de junio de 2016.

\section{Resumen}

La música como interpretación sonora, como idea creativa y como fenómeno social ingresa a los acervos documentales bajo diversas modalidades. La podemos encontrar en el registro de representación sonora y audiovisual cuando se trata de una interpretación o concierto y como registro gráfico en la partitura, ya sea impresa o manuscrita, antigua, moderna o digital y en diversos documentos textuales y gráficos de música o referentes a ella.

Los tipos de documentos en que se plasma la música son librarios (manuscrito, impreso) o libro-música, entre ellos los de música notada, como las partituras, o de

* Universidad Nacional Autónoma de México; Orquesta Sinfónica del Instituto Politécnico Nacional, México. artemis.rg@comunidad.unam.mx; areyesgal@ipn.mx

INVESTIGACIÓN BIBLIOTECOLÓGICA, Vol.30, Núm. 70, septiembre/diciembre, 2016, México, ISSN: 0187-358X. pp. 129-163 
música programada, como los sonoros y audiovisuales. Independientemente de su formato y soporte, el documento testimonia un determinado entorno, que puede ser académico, religioso, comercial, artístico, que refleja el desarrollo de la música así como la destreza de la técnica de escritura manual e impresa o el desarrollo de la tecnología. Puede ser parte de un acervo que comprenda testimonios y trascienda en la memoria de la sociedad. La vasta variedad de documentos y objetos musicales tangibles constituyen la representación o vehículo material de una expresión intangible, como lo es la música, que requiere de un trabajo interdisciplinario para su tratamiento y estudio.

Palabras clave: Música; Documentos musicales; Libros; Partituras; Manuscritos antiguos; Impresos; Incunables; Iconografía.

\section{Abstract}

Collections of musical documents. Rare books, special books?

Artemisa-M. Reyes-Gallegos

Music as sound performance, as creative idea and as a social phenomenon enter documentary archives under diverse categorical modalities. Music created in a performance or concert can be found in the record of sound and audiovisual representation or as graphic records such as a printed or hand-written a musical scores, whether old, modern or digital, as well as in diverse textual and graphic documents of music or referring to music. Music is expressed in an array of document types, including, books of manuscripts or printed materials; musical scores, and audio and audiovisual recordings. Regardless of format or support, a document provides a record of a particular environment, which may be academic, religious, commercial or artistic, while reflecting the development of the music, the technical skill of the composer, as well as development of technology. The record may be part of a collection that stands out in the memory of a people. This wide variety of documents and vast number of tangible musical objects constitute the representation or material vehicle of the intangible expression that is 
music and, as such, shall require an interdisciplinary approach for both study and management.

Keywords: Music; Musical Documents; Books; Sheet Music; Ancient Manuscripts; Printed; Incunabula; Iconography.

\section{INTRODUCCIÓN}

—1 estudio científico, histórico, comparativo y sistemático de la música co- $r$ responde a la musicología, ${ }^{1}$ campo de conocimiento que tiene por objeto la investigación de la música como fenómeno físico, psicológico, estético y cultural; es también la aproximación a la interacción humana con la música en la diversidad cultural y de estilos musicales, es decir, la música como práctica social (Hitchcock y Deaville, s. f.).

Para el análisis e investigación del fenómeno musical, la musicología recurre a gran variedad de documentos, a veces clasificados como raros o de formatos especiales. El documento es herramienta y producto en la investigación musical, el más asociado a la música es la partitura, que tiene características propias en el tratamiento bibliotecológico y archivológico. Además, para el examen de la expresión musical se emplean libros sobre música, publicaciones periódicas y en general todos aquellos escritos que se refieren a esta materia, publicados e inéditos, públicos, privados, incluso los libros sobre libros de música.

La interpretación musical, ya sea instrumental y/o vocal y/o escenificada (concierto, ópera o ballet), no tiene una permanencia en el espacio pues su soporte es la memoria del espectador y del intérprete; es una expresión intangible que actualmente encuentra respaldo en la tecnología para tangibilizarse. Una vez plasmada en algún soporte — sonoro, de imagen o audiovisual - se convierte en documento y conforma acervos, de ese modo se le puede dar tratamiento documental.

El documento musical como recurso de conservación y difusión del conocimiento musical es un elemento del patrimonio cultural intelectual y testimonio escrito de la cultura. El estudio retrospectivo de su evolución

1 El musicólogo Guido Adler la divide en a) histórica: destinada a la historia de la música; b) comparativa: genéricamente conocida como etnomusicología; c) sistemática: incluye acústica y aspectos de fisiología, psicología, estética, sociología, pedagogía y teoría musical. En la práctica abarca la crítica y temas relacionados con la ejecución musical de todos los periodos. 
verifica su indisoluble relación con la función que la música ha desempeñado en el contexto de las diferentes sociedades y momentos culturales, de ahí la importancia de la gestión de los acervos musicales tanto antiguos como modernos y digitales. Aquí nos enfocaremos a la revisión de los documentos musicales librarios y los de música notada, el ámbito de los sonoros y audiovisuales es tan amplio que se mencionarán someramente para contextualizar el universo del documento musical; un análisis detallado deberá ser abordado en otro momento.

\section{LA MÚSICA COMO DOCUMENTO}

Desde un tratamiento bibliotecológico, los documentos musicales pueden adscribirse a variados criterios. Así, con base en la forma de representación del mensaje en el soporte físico, se pueden mencionar los siguientes: ${ }^{2}$

- Gráfico: partituras, libros, revistas, programas de mano, libretos, etc.

- Iconográfico: fotografías, pinturas, grabados, carteles, libros iluminados, esculturas, etc.

- Fónico: cilindros, discos, carretes, cintas magnetofónicas, etc.

- Audiovisual: películas, videos, etc.

- Plástico: instrumentos musicales, objetos.

- Electrónico: disquetes, discos óptico digitales, dispositivos de lectura óptica, etc.

La descripción de documento, a partir de la definición de la Unesco, abarca las siguientes variedades: textuales o escritos, no textuales (gráficos), audiovisuales (incluye los sonoros) y virtuales. En la musicología las fuentes documentales son escritas, de imagen, sonoras y audiovisuales. De los documentos escritos, manuscritos o impresos, los principales son partituras, apuntes, libros y revistas; los de imágenes fijas pueden ser grabados, iconografía (imágenes planas, tallas exentas y esculturas), fotografías; entre los documentos de imágenes en movimiento tenemos cine, videos, animaciones; los documentos sonoros incluyen fonogramas analógicos y digitales y los audiovisuales (Tabla 1). Bravo (2002: 75). 
Tabla 1. Principales tipos de fuentes documentales musicales

\begin{tabular}{|c|c|c|}
\hline - Documentos escritos & $\begin{array}{l}\text { - Manuscritos } \\
\text { - Impresos } \\
\text { - Digitales }\end{array}$ & $\begin{array}{l}\text { - Partituras } \\
\text { - Apuntes } \\
\text { - Libros } \\
\text { - Revistas } \\
\text { - Libretos }\end{array}$ \\
\hline \multirow[t]{2}{*}{ - Documentos de imagen } & - Fija & $\begin{array}{l}\text { - Grabados } \\
\text { - Iconografía } \\
\text { - Fotografía } \\
\text { - Mapas } \\
\text { - Pinturas } \\
\text { - Diapositivas } \\
\end{array}$ \\
\hline & - En movimiento & $\begin{array}{l}\text { - Películas (sin sonido) } \\
\text { - Presentaciones animadas (sin sonido) }\end{array}$ \\
\hline - Documentos sonoros & $\begin{array}{l}\text { - Analógicos } \\
\text { - Digitales }\end{array}$ & $\begin{array}{l}\text { - Fonogramas de música } \\
\text { - Fonogramas de la palabra } \\
\text { - Fonogramas de paisaje sonoro }\end{array}$ \\
\hline - Documentos audiovisuales & $\begin{array}{l}\text { - Combinación de imagen en } \\
\text { movimiento con sonido }\end{array}$ & $\begin{array}{l}\text { - Cine } \\
\text { - Videos } \\
\text { - Animaciones } \\
\text { - Multimedia } \\
\text { - Producciones televisivas }\end{array}$ \\
\hline
\end{tabular}

Otra definición, que atiende al código de transmisión del mensaje (Rodríguez Bravo, 2002: 77) y a la que se han agregado ejemplos de la documentación musical, comprende:

- Textuales: con $\operatorname{signos}^{3}$ de lenguas escrita y/o notación musical.

- Gráficos: escenografías, coreografías, evoluciones, planos, diagramas, etc.

- Iconográficos: pinturas, grabados, diapositivas, fotografías, etc.

- Sonoros o fónicos: cintas, cilindros, carretes, discos, casetes, dispositivos de lectura óptica.

- Audiovisuales: películas, videos, imágenes en movimiento.

- Plásticos o tridimensionales: instrumentos u objetos y accesorios musicales, generalmente expuestos en museos y exposiciones.

- Informáticos: de lectura digital por medio de computadora o dispositivos de lectura óptica.

- Multimedia: documentos digitales que combinan varios códigos de lectura óptica.

3 En música, cualquiera de los dibujos que representan sonidos [y silencios] o cualquier indicación para la ejecución (Moliner, 2002). 
El calificativo "documento" para las modalidades sonoras y audiovisuales es bastante reciente y sólo últimamente se ha incrementado su difusión, pues se conservaba la idea de que el documento es papel, o por lo menos algo tangible y descifrable visualmente. Según la archivística, los documentos audiovisuales son los que transmiten la información a través de imagen y/o sonido y abarcan tres grupos: imagen fija, imagen móvil y registros sonoros (Arévalo, 1991). El término audiovisual se aplica a "películas de imagen fija y de movimiento y microfilmes, registros de sonido, diapositivas, maquetas y modelos mecánicos, cuadros murales, tarjetas y carteles” (Unesco, 1948: art. II).

La Recomendación sobre la salvaguarda y la conservación de imágenes en movimiento de la Unesco (1980: I.1.a) asigna la denominación de "imágenes en movimiento" a "cualquier serie de imágenes registradas en un soporte [...] con o sin acompañamiento sonoro, que, al ser proyectadas, dan una impresión de movimiento y están destinadas a su comunicación o distribución al público o se producen con fines de documentación".

Por su parte, la Norma Mexicana de Catalogación de documentos fonográficos (COTENNDOC, 2008: 19) nos dice que documento sonoro o fonográfico es "el soporte físico donde se toma registro de cualquier sonido (música, voz humana y otros) mediante un procedimiento analógico o digital, reconocido como un producto cultural que transmite conocimientos, ideas, emociones y da testimonio de hechos".

\section{LA EXPRESIÓN MUSICAL SONORA COMO DOCUMENTO TANGIBLE}

El parteaguas en el estudio de la interpretación musical se dio a fines del siglo XIX, cuando los registros sonoros hicieron su aparición en el campo de la música, expresión temporal e intangible, permitiendo que lo efímero se mantuviera en el tiempo y en el espacio, pues nos relatan de manera auditiva, una y otra vez, el hecho musical sonoro. La tecnología nos permite transformar las expresiones intangibles en documentos tangibles, de manifestaciones inmateriales y fugaces a registros sonoros y audiovisuales plasmados en formatos analógicos y digitales. Otro tipo de documento impreso es la fotografía, que mediante imagen fija plasma la actividad musical.

El estudio de la interpretación musical — conciertos y representaciones escénicas - ha sido posible a partir del registro textual de testimonios presenciales que contienen su descripción, narración, crítica o reseña; otro acercamiento a la comprensión de la ejecución musical se verifica en la revisión hemerográfica, y por supuesto en menciones y referencias de carácter literario y de la iconografía. 
La musicología se auxilia, en algunos casos, de objetos tridimensionales que se pueden considerar fuentes documentales, como las esculturas, algunos ejemplos de arquitectura y artes menores. Otra modalidad de documentación musical es el estudio organológico de instrumentos musicales antiguos y tradicionales y sus accesorios; algunos han sido registrados en publicaciones técnicas de laudería. Esa bibliografía especializada contiene planos, diagramas, fotografías, etc., que sustentan su estudio y reproducción, estas ediciones constituyen fuentes documentales de investigación. En sentido inverso, es decir, cuando por medio del estudio de aquellos instrumentos antiguos se pueden elaborar planos y diagramas para construir réplicas lo más fieles posibles que nos den una aproximación de la sonoridad de los instrumentos originales, el documento es el mismo instrumento (Ilustración 1).

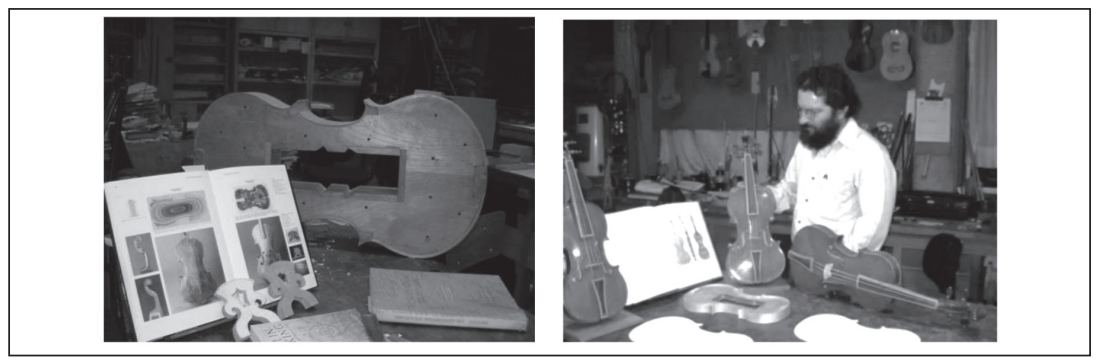

Ilustración 1. Del documento al instrumento y del instrumento al documento: fuentes documentales organológicas Fuente: la autora

\section{TESTIMONIOS SILENCIOSOS DEL SONIDO MUSICAL}

Para dar referencia de las expresiones sonoras, existen otros testimonios musicales silenciosos: las partituras, los tratados, los estudios y los textos de y referentes a la música, que conforman una gran variedad del patrimonio musical tangible. Por medio del análisis de la información que contienen sabemos de los estilos de la música, el gusto del público y el contexto social de obras, compositores e intérpretes. Estos testimonios textuales y gráficos conservados en archivos, bibliotecas o museos institucionales, religiosos y particulares, son material de investigación y reflexión en la musicología.

Los archivos musicales preservan entre signos, grafías, glosas, líneas e imágenes la memoria de una historia próxima o remota, individual o colectiva; son testimonio de códigos sociales, convenios y convenciones pasados, reseña de derechos, prácticas y apreciaciones personales y sociales. Corroboran actos y disposiciones pretéritas, la evolución de instituciones y orga- 
nizaciones, la vida de personas, los valores, gustos, creencias y convicciones en que se sustentaron, así como usos y costumbres (WCCD, 1996: 228-229) refieren las relaciones entre las personas y las comunidades, de éstas con la naturaleza y de los individuos con el medio en que habitan y que imaginan.

Las fuentes documentales musicales, por su variedad de soportes, formato, origen y antigüedad, se hallan dispersas en reservorios públicos, universitarios, escolares, de conservatorios, fonotecas, mediatecas, fototecas, radiodifusoras y televisoras, archivos eclesiásticos, centros de documentación e información y museos; no menos importantes cualitativa y cuantitativamente son las resguardadas en archivos y colecciones personales y privadas. La organización de los acervos personales y privados no suele regirse por criterios bibliotecológicos, incluso en algunas ocasiones son de carácter musicológico.

La información musical distribuida en colecciones de manuscritos, de libros raros y antiguos o de formatos especiales se puede organizar por soporte y formato -partituras, libros y publicaciones periódicas o documentos sonoros y audiovisuales-; por época -antiguos, coloniales, novohispanos, por siglo-; por origen de creación -mexicanos, europeos, etc.-; de donación o adquisición o de autor. Su conformación puede abarcar monografías de un compositor, un intérprete o un algún personaje, análisis musicales de una obra, de una época de la historia de la música, de estilos o géneros musicales, así como ediciones comentadas o críticas, facsímiles de partituras, publicación de la investigación musicológica o pedagógica o actas de coloquios, etc.

Los repositorios con acervos antiguos custodian manuscritos e impresos, grabados, cartografías, dibujos; los que contienen materiales no tan antiguos, también fotografías. Los archivos de música y músicos incluyen partituras manuscritas e impresas, documentos textuales y gráficos e incluso instrumentos musicales y registros sonoros con sus equipos reproductores. Con las nuevas tendencias musicológicas se ha creado conciencia de la importancia de la interdisciplina y las ventajas de las nuevas tecnologías, así, en los archivos con colecciones en este campo es posible encontrar fuentes de diferentes disciplinas.

\section{LOS DOCUMENTOS MUSICALES LIBRARIOS}

Los acervos documentales se conforman con items de muy variadas características. Una clasificación general basada en el soporte y formato los divide en librarios y no librarios (Rodríguez Bravo, 2002: 77; Torres Mulas, 2000: 744); la primera atiende "estrictamente a su apariencia y materialidad, al margen de su contenido [en el que el libro es] el conjunto de hojas de cualquier materia escriptoria, manuscritas o impresas y unidas entre sí por uno 
de los lados" (Torres Mulas, 2000: 743). El Glosario de términos bibliotecarios RDIB (s. f.: s. p.) define libro como "obra impresa o manuscrita no periódica que consta de muchas hojas de papel, pergamino, vitela u otro material, cosida o encuadernada que se reúne en un volumen. Cada una de ciertas partes principales en que suelen dividirse las obras científicas o literarias, y los códigos y leyes de gran extensión”.

Las Reglas de Catalogación españolas (RC) definen físicamente a los libros como "el conjunto de hojas de cualquier materia escriptoria, manuscritas o impresas y unidas entre sí por uno de los lados [que] si no pasa de cincuenta páginas, se llama folleto" (Dirección General del Libro, 1999: 584). ${ }^{4}$ El Consejo Nacional de Ciencia y Tecnología (Conacyt) de México lo define como:

trabajo impreso con fecha (año) y mención de una editorial reconocida como tal, generalmente en las primeras páginas. Suele tener una extensión de más de 100 páginas. [...] puede haber opúsculos, cuadernos o textos editados, más pequeños que un libro [que son considerados como libros por el CONACYT a falta de una categoría apropiada a este tipo de obras]. Los libros publicados en CD con ISBN serán considerados en el mismo nivel que los libros impresos. (Conacyt, s. f.: 25)

Los documentos musicales librarios tienen variantes como "libros-texto" y "libros-música"; a los últimos, en el ámbito musical, se les denominan partitura o papeles de música. Los no librarios son los registros sonoros y los audiovisuales. Otra clasificación registra los documentos musicales como música notada o anotada (impresa o manuscrita, partituras), música programada (registros sonoros y audiovisuales), documentación de carácter personal y documentación funcional (Cabezas Bolaños, 2005: 88-89; Burgos Bordonau y Petrescu, 2011: 1-2), algunas más los dividen en libros, partituras y sonido (grabaciones sonoras) (EUDOM, 2007: 15). Las RC las señala como música impresa (o manuscrita) y música grabada.

Cada uno de los tipos documentales musicales tiene características propias, ya relacionadas directamente con la música, ya por su apoyo al estudio e investigación musicológica. En el presente trabajo se ha optado por distinguirlos como documentos escritos o librarios y documentos sonoros y audiovisuales o no librarios.

Como documentos librarios o escritos se encontraron varias tipificaciones en la revisión de las diferentes escuelas y autores. La categoría de lo librario incluye biografías de creadores o intérpretes, historias de instituciones

4 A fin de abundar y complementar la información se han consultado las Reglas de Catalogación Angloamericanas (AACR2) (Gorman y Winkler, 1999) y las Reglas de Catalogación (Dirección General del Libro, 1999). 
relacionadas con la actividad musical, textos sobre teoría y análisis estilísticos y técnicos, ensayos históricos, disertaciones filosófico-musicales, apreciación musical, técnicas compositivas, interpretación musical, evolución de los instrumentos, etc. La Clasificación de la EUDOM (2007: 19-21) considera los rubros que se muestran en la Tabla 2.

Tabla 2. Obras de referencia

\begin{tabular}{|l|l|}
\hline$\bullet$ Actas de congresos & $\bullet$ Almanaques-calendarios \\
\hline$\bullet$ Bibliografías & $\bullet$ Bio-bibliografías \\
\hline - Catálogos & $\bullet$ Cronologías \\
\hline - Diccionarios & $\bullet$ Efemérides \\
\hline - Enciclopedias & $\bullet$ Escritos introductorios y generales sobre música \\
\hline - Fonografías & $\bullet$ Iconografías \\
\hline$\bullet$ Índices bibliográficos & $\bullet$ Índices temáticos \\
\hline - Léxicos & $\bullet$ Manuales \\
\hline • Musicografías & $\bullet$ Obras de tratamiento de la documentación musical \\
\hline$\bullet$ Repertorios musicales & \\
\hline
\end{tabular}

A los "libros" que directa o indirectamente aportan información para el conocimiento de la música en todos sus campos se les conoce como bibliografía de carácter perimusical porque su contenido "alude conceptualmente a entes o actividades vinculados con la música” (Torres Mulas, 2000: 745) o porque permiten vincular información con los campos del pensar, el saber y el hacer musical. Para un tratamiento bibliotecológico se clasifican por la materia de la cual tratan sus contenidos (EUDOM, 2007: 13) (Tabla 3):

Tabla 3. Biblioteca de contenido perimusical

\begin{tabular}{|l|l|}
\hline • Biblioteca de complemento & $\bullet$ Etnomusicología \\
\hline - Fundamentos generales de la musicología & $\bullet$ Historia de la música \\
\hline$\bullet$ Instrumentos musicales y su historia & $\bullet$ Música y otras ciencias y artes - Varios \\
\hline - Obras de referencia & $\bullet$ Pedagogía musical \\
\hline - Vida musical - Comercio musical - Instituciones musicales & $\bullet$ Teoría de la música - Ejecución musical \\
\hline
\end{tabular}

Los archivos de carácter musical concentran fondos documentales y colecciones musicales tratados de acuerdo con su naturaleza y volumen y divididos en tres tipos (Cabezas Bolaños, 2005: 88):

- Las colecciones de obras musicales, reunidas por intérpretes o coleccionistas.

- Fondos, producto de un proceso natural y voluntario de una persona física o jurídica y que reflejan sus actividades musicales y personales. 
- Conjunto de documentos que ingresan en forma desordenada e incoherente y para los cuales no es posible reconstruir su organización primitiva, ya sea por la dispersión o porque nunca la tuvieron.

Con base en esta tipología Cabezas Bolaños (2005) propone la siguiente clasificación para su agrupación en el fondo:

- De carácter musical: música anotada y música programada.

- De carácter personal: "documentos muy diversos, desde memorias, agendas, diarios, correspondencia [...], hasta documentos de estado civil o eclesiástico como partidas o certificados de bautismo, boda, defunción o divorcio; [...] documentos de identificación personal como cédulas, pasaportes, certificados de estudios, títulos académicos o profesionales, o documentación de carácter de salud [...], ordenados numéricamente" (Cabezas Bolaños, 2005: 88).

- Funcional: la generada en el ejercicio de una función pública o privada no necesariamente relacionada con la música. No es recomendable que la documentación generada en diversas actividades por el mismo personaje sea separada, es preferible que sean tratadas conjuntamente y en orden cronológico. Esto porque el origen funcional es la razón por la que se produce el documento, lo que está directamente relacionado con las actividades privadas y cotidianas de una persona.

Los anteriores documentos son testimonio del quehacer musical, de actividades públicas, privadas, familiares, artísticas o de investigación, docencia y difusión; toca al investigador determinar la importancia en su labor. En el caso de los documentos musicales-partituras, su uso histórico "evidencia la existencia de la obra musical y su interpretación en el pasado, ya que tras ambos: la partitura, la interpretación [y las grabaciones], persiste el concepto de creación de la obra en sí misma" (Smiraglia, 2001: 3).

De acuerdo con el medio de transmisión del mensaje, los documentos se tipifican como sigue (Rodríguez Bravo, 2002: 81):

- Textual. Información escrita por medio de signos y grafías: libros, publicaciones periódicas, documentos administrativos, bibliografías, entre otros. Se leen sin necesidad de ninguna herramienta dispositivos o equipos de lectura

- Especial. Su información esencial aparece con signos particulares aunque puede incluir una parte de texto. De estructura muy variable en relación a la naturaleza de su soporte. Debe verse, oírse o manipularse. 
Entre este tipo de documentos se encuentran los iconográficos, plásticos, sonoros, mixtos, audiovisuales e informáticos.

Cabe destacar que la Unesco, en el Informe Mundial sobre Cultura 20002001. Diversidad cultural, conflicto y pluralismo (Arizpe, 2001) incluyó a la música en el área de cultura; las estadísticas que acompañan dicha publicación la sitúan junto con el cine, la televisión y el deporte. Las estadísticas sobre productos editoriales presentan al libro de música en la categoría de libro de arte, en el mismo nivel de las obras sobre cine, pintura, fotografía o de entretenimiento.

\section{DOCUMENTOS ANTIGUOS Y MANUSCRITOS}

Los criterios de clasificación relacionados con la datación que atienden a la época de producción, el proceso escriturario y la plasmación de escritura determinan el calificativo de "libro antiguo", manuscrito o impreso. ${ }^{5}$ No se ha logrado consensuar una delimitación temporal al libro antiguo pues cada fuente determina la fecha; así, las RC fijan 1801, la Federación Internacional de Asociaciones de Bibliotecarios y Bibliotecas (IFLA) en su Descripción Bibliográfca Internacional Normalizada para Publicaciones Monográficas Antiguas (ISB$\mathrm{D}(\mathrm{A}))^{6}$ y la bibliografía francesa establecen como límite el año 1820, en tanto que el Consorcio de Bibliotecas Europeas de Investigación determina 1830.

Impresos y manuscritos confluyen en el ámbito de la valoración y tasación del libro antiguo y la librería anticuaria, si bien los términos libro viejo, libro raro, libro precioso y fondo antiguo se usan erróneamente como sinónimos (Pedraza García, 2004: 13). El mercado del libro antiguo admite el límite en la primera mitad del siglo XIX. De manera general el calificativo se aplica a los libros producidos con anterioridad al primer tercio del siglo XIX (Tacón Clavaín, 2004: 2) y al libro de más de 100 años (Pedraza García, 2004: 13). El libro manuscrito es un documento cuyo texto es elaborado o copiado a mano. Manuel Sánchez Mariana nos dice que:

aunque hay manuscritos de todas las épocas, desde que empiezan a escribirse libros hasta hoy, forzosamente hemos de referirnos en especial a la época en que la

5 El libro manuscrito no siempre se consideró libro antiguo ni objeto de la Bibliografía. Fue ante la necesidad de diferenciar entre documentos manuscritos, impresos y digitales, que se aceptó como material bibliográfico si cumple con los parámetros de antigüedad (Reyes Gómez, 2003: 12).

6 ISBD(A). International Standard Bibliographic Description for Older Monographic Publications (Antiquarian). 
producción del libro a mano es más significativa: la larga etapa de la historia de la humanidad que se extiende desde los más antiguos testimonios librarios que han llegado a nosotros hasta la segunda mitad del siglo XV, cuando en Centroeuropa se inventa un procedimiento para reproducir en copias múltiples la escritura de los libros. Las edades Antigua y Media son por antonomasia las épocas del libro manuscrito [...] (Sánchez Mariana, 1995: 7)

La forma característica del libro de la Edad Media es el codex o códice, ${ }^{7}$ en música existen importantes estudios sobre códices de partituras. Otro periodo en la elaboración de los manuscritos es aquel en que conviven con los libros impresos; en la literatura especializada, este tipo de manuscrito es señalado como manuscrito de la Edad Moderna o manuscrito moderno. La acepción generalizada es que la invención de la imprenta en 1435 es el punto nodal, pues antes de ésta todos eran manuscritos.

Entre las definiciones para catalogación de manuscrito las AACR2 (Gorman y Winkler, 1999) citan: "escritos hechos a mano (incluyendo partituras musicales, mapas, etc.) o texto mecanografiado (typescript(s)); así como las inscripciones en tabletas de arcilla, piedra, etc." (689) y "listados de todas clases, incluyendo libros, tesis o disertaciones, cartas, discursos, etc., textos legales manuscritos (incluyendo formas impresas completadas a mano) y colecciones de tales manuscritos" (135). Las RC destacan que es un "papel o libro escrito a mano" o un "original o copia de un texto destinado a ser impreso, aun cuando no esté escrito a mano” (585). La producción libraria musical ha seguido una trayectoria similar a la de la producción libraria general.

\section{LA MÚSICA EN PARTITURAS MANUSCRITAS E IMPRESAS}

Entre los documentos musicales catalogados como librarios se distinguen los manuscritos e impresos y aquellos con grafía específicamente musical, denominados partitura, papel de música o música anotada o notada. Definiciones bibliográficas de partitura la citan como documento que "muestra todas las partes de un conjunto pensadas para ser oídas al mismo tiempo, normalmente dispuestas una debajo de otra en diferentes pentagramas" (Iglesias Martínez y Lozano, 2008: 205) o bien, el "ejemplar musical en el que aparecen

7 En la historia del libro se acepta que el uso del pergamino va unido al cambio en la forma del códex o códice: del rollo de papiro se pasa la encuadernación del pergamino. El códice permaneció como la forma del libro habitual desde aproximadamente el siglo III y es la forma más extendida del libro durante el medievo (Sánchez Mariana, 1995: 8-9; Arévalo, 1991; McCleary, 1997; Moliner, 2002). 
superpuestas en una misma página todas las partes vocales y/o instrumentales de una obra" (GTCCPB, 2010: 144). Al que usa el director también se le nombra score.

En los conjuntos musicales —orquestales, vocales, y mixtos- al documento con escritura y anotaciones musicales que corresponde a cada uno de los integrantes del ensamble se llama parte o particella (partitura de cada voz o instrumento). Partitura es el papel de música notada correspondiente a un instrumentista o cantante "que contiene todo lo que deber realizar [en la interpretación musical] solo o en conjunto" (Bañuelas, 2009: 105), serie de notas escritas para ser ejecutadas por una voz o instrumento tanto solo como en conjunto con otras voces o instrumentos (Baker, Slominsky y Kuhn, 1995). Coloquialmente, tanto score como particellas son identificadas genéricamente como partitura.

La característica de partituras y de particellas es que el registro de sus signos corresponde a algún sistema de notación musical: tablatura, cifrado, notación neumática, cuadrada, mensural, contemporánea, cifrados alfabéticos, etc., cuya lectura e interpretación posibilita la reproducción de la obra musical (Cabezas Bolaños, 2005: 92; Torres Mulas, 2000: 746). La partitura es el medio que facilita la escritura de la creación y su consecuente interpretación, pues "mientras la interpretación no se produce, la obra musical no es sino un proyecto del que no se puede disfrutar" (Prieto Guijarro, 2011: 4). Documento musical por excelencia, la partitura representa gráficamente la concepción musical del compositor, es herramienta para el intérprete y fuente de conocimiento para el musicólogo.

La partitura es un registro para la difusión de la obra musical; sin embargo, la presencia de ésta en el ámbito de la interpretación, como pauta de observancia, no es una constante en la historia de la interpretación, ya que como señala Colin Lawson (2011: 23-26):

las melodías eclesiásticas no fueron escritas sino hasta el siglo VI, y sólo en el siglo XII se ideó un sistema para indicar las alturas de los sonidos, aunque no su valor exacto [...] [Por ello] una de las principales dificultades para recrear la música medieval es que la improvisación y el acompañamiento instrumental no están presentados en las notaciones que se han conservado.

Todavía hoy, con la evolución de los sistemas de notación musical, las partituras no reflejan la totalidad de la realidad interpretativa, pues los intérpretes aportan a la obra una parte importante de su personalidad. La notación sigue siendo una aproximación a la intención musical del compositor, si bien es el documento más representativo de la memoria musical per se, así como elemento fundamental para el conocimiento y la interpretación musical pues con el 
tratamiento adecuado de conservación es objeto estable y permanente (Burgos Bordonau y Petrescu, 2011: 33); desde las perspectivas paleográfica y diplomática, la partitura es herramienta de validación y autenticidad en el transcurso del tiempo.

Para la catalogación y, en general, para la descripción bibliográfica de la música anotada manuscrita e impresa, se emplean diversas designaciones específicas en razón de su contenido y distribución, descripción física, función y destinatarios (Apéndice 1). De igual forma, se cuenta con una clasificación por tipología en la catalogación de documentos librarios con música notada (GTCCPB, 2010: 53-108), aquí complementada con ejemplos musicales específicos:

- Partituras (manuscritas o impresas): partitura, partitura abreviada, guión, partitura de estudio, parte de piano director, violín director, etc., partitura vocal, reducción para piano, etc.

- Libros litúrgicos que específicamente contienen las partes de la liturgia con música: liber usualis, misal romano, graduale, himnarios, góspel, salterios, etc.

- Archivos musicales, personales o de entidad, integrados con música notada principalmente: se conforman con gran variedad de documentos relacionados con el carácter y actividad del personaje o institución.

La clasificación sistemática de partituras de la EUDOM considera la formación musical y/o vocal, de solos y ensambles, familias de instrumentos, inclusive los mecánicos y electrónicos; formatos de presentación; las colecciones por géneros y tipos de colecciones: por ediciones, por antologías, por soportes especiales.

Es importante considerar que una misma pieza musical puede encontrarse en diferentes versiones y ediciones en partituras con arreglos y transcripciones de varios autores, en versiones para piano solo, para dos pianos, para piano a cuatro manos, para piano y otro(s) instrumento(s) melódico(s) y/o armónico(s) o para piano y voz o coro, para banda o para otro tipo de ensambles instrumentales, asimismo, pueden existir versiones transcritas en distintas tonalidades, simplificadas, arreglos, etc., que siempre deben ser incluidas en el catálogo de manera separada (Brenne, 2004: 53-108); todas estas versiones son fuentes documentales para la interpretación, la docencia y la investigación.

Es posible encontrar notación musical ilustrando documentos librarios catalogados como monografías, por ejemplo, en los métodos de estudio, los repertorios con extractos de pasajes musicales sinfónicos, de ópera, etc.; los cancioneros y libros de baile; aquella usada para ilustrar los textos de trata- 
dos musicales o que complementan estudios críticos; que pueden ser ejemplos útiles para la interpretación musical (GTCCPB, 2010: 5).

Las partituras manuscritas, producto de la práctica previa a la invención de la imprenta, son el soporte musical con más larga trayectoria pues abarcan desde su surgimiento como registro nemotécnico hasta su elaboración como material para la interpretación y difusión musical; se encuentran en soportes minerales, pergamino y papel, escritas con diversas grafías, símbolos, tablaturas y sistemas de notación musical antigua y contemporánea. La lectura de las partituras antiguas, debido a los cambios en los sistemas de notación musical, se apoya en la paleografía musical ${ }^{8}$ y en el conocimiento diplomático a fin de verificar, entre otros, su autenticidad, origen y factura. La aparición de la música impresa puede rastrearse con la invención de la imprenta musical.

En los archivos y bibliotecas, las partituras se suelen catalogar en las secciones de música práctica y libros teóricos, litúrgicos y métodos, cuando la biblioteca no es especializada o no cuenta con sección de música se les ubica en las secciones de manuscritos, manuscritos varios, incunables o libros raros.

La producción de partituras manuscritas ha permanecido como práctica frecuente, la grafía manuscrita se ha mantenido incluso en el siglo XXI en la escritura musical hecha por particulares. Gran cantidad de las obras deben su difusión a una copia manuscrita y una fotocopia, es así como las encontramos en muchos archivos corales, orquestales y ensambles de todo tipo y, de manera destacada, en los acervos personales. Desde fines del siglo XX la tecnología digital llegó a la edición de música notada, que hoy subraya lo cotidiano de la reproducción de partituras por medio de fotocopias y recientemente del escáner y la fotografía digital, opciones muy favorecidas en la práctica musical, al grado de que en no pocos casos son ordinarios en los acervos particulares e incluso orquestales. ${ }^{9}$

\section{Colecciones facticias}

La vinculación entre la obra musical y su interpretación sonora es la partitura, la primera es un proyecto concebido por el compositor que no se concreta

8 Estudio de sistemas de notación musical antigua y tablaturas. Dom André Mocquereau introdujo el término en el título del primer volumen de la serie de la edición monumental de música de canto llano basada en el estudio de los manuscritos antiguos, Paléographie musicale (1889), publicada por los monjes de la Abadía de Solesmes, Francia; locución con la que se identifica también al conjunto de esa publicación.

9 Los de las orquestas sinfónicas, conjuntos de cámara, coros, bandas y diversos conjuntos clásicos, religiosos y populares, con fines didácticos, culturales, comerciales y de difusión. 
sino hasta que se produce la segunda. Tanto el compositor como la obra y el o los intérpretes son reflejo de un contexto, y es que las obras de alguna manera son representaciones de pensamientos, épocas, concepciones de sus creadores y vínculo entre éstos y los ejecutantes con el público, con la academia, con los investigadores (Smiraglia, 2001: 2). Como fuente de conocimiento, la partitura es un documento que proporciona información "respecto de la obra musical, al margen de la posibilidad o no de su escucha" (Prieto Guijarro, 2011: 4). Como producto humano pertenece a una realidad determinada por las circunstancias históricas, sociales, intelectuales, artísticas, laborales en que la obra fue concebida originalmente; a ello se adiciona el contexto de las representaciones e interpretaciones posteriores, que van modificando el sentido expresivo y en ocasiones hasta la intención dialéctica, pues las condiciones en que se realizan las ejecuciones subsecuentes corresponden a una realidad diferente a la de la creación (Brenne, 2004: 35), incluso del estreno y de la grabación.

Es frecuente que los músicos organicen sus partituras en colecciones facticias. Facticia, nos dice el Diccionario de uso del español, es un vocablo derivado del latín factičus, que significa artificial o fabricado; se aplica a las cosas hechas o fabricadas arbitrariamente y no fundadas en la naturaleza de la cosa que se trata (Moliner, 2002). En la terminología documental se aplica al ejemplar que "contiene obras distintas que han sido encuadernadas juntas; en un mismo volumen se reúnen ejemplares unitarios de diferentes ediciones" (Clemente San Román, 2003: 254), en general se dice de un volumen de tipo misceláneo que se compone de distintos papeles, también de distintas épocas, producidos por varias manos o manufacturas e incluso pudieran ser de medidas diversas. En el vocabulario bibliotecológico se entiende la colección o "volumen formado con piezas heterogéneas cuya reunión bajo una misma encuadernación sólo se justifica por necesidades de conservación en una biblioteca o archivo, no por una relación natural existente entre ellas [...] algunas veces conforman un repertorio musical organizado de partituras sueltas" (citado en Escalada, 2009: 2); es también, la reunión de documentos de origen misceláneo, que debe su origen al deseo del investigador (Arévalo, 1991). Recurriendo a las RC, encontramos que la colección facticia es un "volumen que resulta de encuadernar juntas obras publicadas independientemente", se trata de un conjunto de materiales gráficos "realizados independientemente y reunidos con posterioridad en uno o varios volúmenes, carpetas, etc." (Dirección General del Libro, 1999: 571/RC, 571), se conforma por los documentos que "se han producido independientemente y estaban exentos hasta que en un momento determinado, posterior a su producción, se encuadernaron juntos” (GTCCPB, 2010: 12). 
En el ámbito de la biblioteca musical, las colecciones facticias son considerablemente típicas tanto en los acervos institucionales, particularmente en fondos antiguos, como en los personales y, quizá, más comunes en éstos. Su organización, realizada por el músico — profesional, estudiante o aficionado - responde a necesidades propias de su actividad o interés musical, por ello, "no siempre es fácil encontrar el hilo que ha llevado a la formación de una colección concreta, pues existen intereses variados" (Iglesias Martínez y Lozano, 2008: 46). Algunos ejemplares son de interés para el estudio musicológico, conocidos genéricamente como cuadernos o códices y objeto de ediciones críticas. Estos cuadernos se conforman con base en diferentes exigencias o ventajas, entre las que se pueden mencionar las siguientes: ${ }^{10}$

- Colecciones para el estudiante. Organizadas por nivel de dificultad, por género, por función didáctica, etc. Frecuentemente con marcas de dinámica y agógica, pasajes técnicos o expresivos resaltados y consejos de interpretación y glosas.

- Colecciones para la actividad profesional. Contienen un repertorio útil para la actividad regular y pretenden facilitar su traslado y manejo. Se les encuentra para un instrumento y/o para conjuntos, cada cuaderno contiene las particellas de un solo instrumento (o voz) y se complementa con los demás cuadernos.

- Conjuntos de obras para eventos sociales y religiosos como bailes, reuniones, ceremonias, misas, etc.

- Conjuntos de partituras organizados por coleccionistas o aficionados. Compilan obras de un compositor determinado, de un género específico, de un país en especial, de un editor en particular o música para determinado tipo de evento

En estos volúmenes las encuadernaciones son por sí mismas objeto de estudio debido a que aportan referencias sobre los propietarios, el contexto social, los gustos y usos de época. Cabe añadir que editores y libreros también preparan cuadernos facticios de carácter misceláneo atendiendo a necesidades académicas o a intereses de gusto y popularidad; en cualquier caso, son colecciones reveladoras del estado de la difusión y funciones de la música.

El tratamiento catalográfico de archivos y bibliotecas para los fondos musicales documentales de cada ejemplar nos permite: 
conocer una colección, su origen, su proceso de formación y su estado de conservación; estudiar la repercusión de las normas legales en la formación y desarrollo de las colecciones; favorecer la investigación con información sobre la difusión de la música y sus agentes de venta (editores, libreros); [saber de] el uso profesional que se le ha dado a las partituras, [...] las anotaciones manuscritas tanto de propiedad, como las de arreglos en el pentagrama, o su propia encuadernación. (Iglesias Martínez y Lozano, 2008: 455-456)

\section{Catálogos de \\ DOCUMENTOS MUSICALES ANTIGUOS, MANUSCRITOS, IMPRESOS E INCUNABLES}

Para la catalogación de las fuentes musicales existen cuatro proyectos cooperativos internacionales de documentación bibliográfica en el campo de la investigación musical: Répertoire International des Sources Musicales (RISM), Répertoire International de Littérature Musicale (RILM), Répertoire International de la Presse Musicale (RIPM) y Répertoire International d'Iconographie Musicale (RIdIM), además de empresas dedicadas a la catalogación y clasificación de documentos musicales incunables y ediciones facsimilares.

El Répertoire International des Sources Musicales (RISM), fundado en 1952 y conformado por grupos de trabajo, entre ellos México, desarrolla un proyecto multinacional para construir un amplio catálogo de fuentes musicales primarias manuscritas, impresas, escritos referentes a la música y libretos resguardados en bibliotecas, archivos, museos, monasterios, escuelas y colecciones privadas. Desarrolla sus actividades bajo los auspicios de las asociaciones de profesionales como la International Association of Music Libraries, Archives and Documentation Centres (IAML) y la International Musicological Society (IMS) y del Council for Philosophy and Humanistic Studies (CIPSH) UNESCO y en coordinación con las bibliotecas estatales Bávara y su Biblioteca virtual de musicología (Munich), la de Berlín, el Clori-archivo de la Cantata Italiana y la Lista de fuentes Richard Strauss. Sus publicaciones impresas y en línea- dirigidas a musicólogos, músicos intérpretes, bibliotecarios y músicos anticuarios, se dividen en tres series (RISM, 2015) (Tabla 4).

Tabla 4. Publicaciones del Répertoire International des Sources Musicales (RISM)

\begin{tabular}{|l|l|}
\hline $\begin{array}{l}\text { Inventario de fuentes } \\
\text { musicales }\end{array}$ & $\begin{array}{l}\text { - Documentos musicales impresos individuales, publicados entre 1600-1800 } \\
\text { - Música manuscrita después de 1600, incluye manuscritos, música impresa, } \\
\text { libretos y tratados }\end{array}$
\end{tabular}




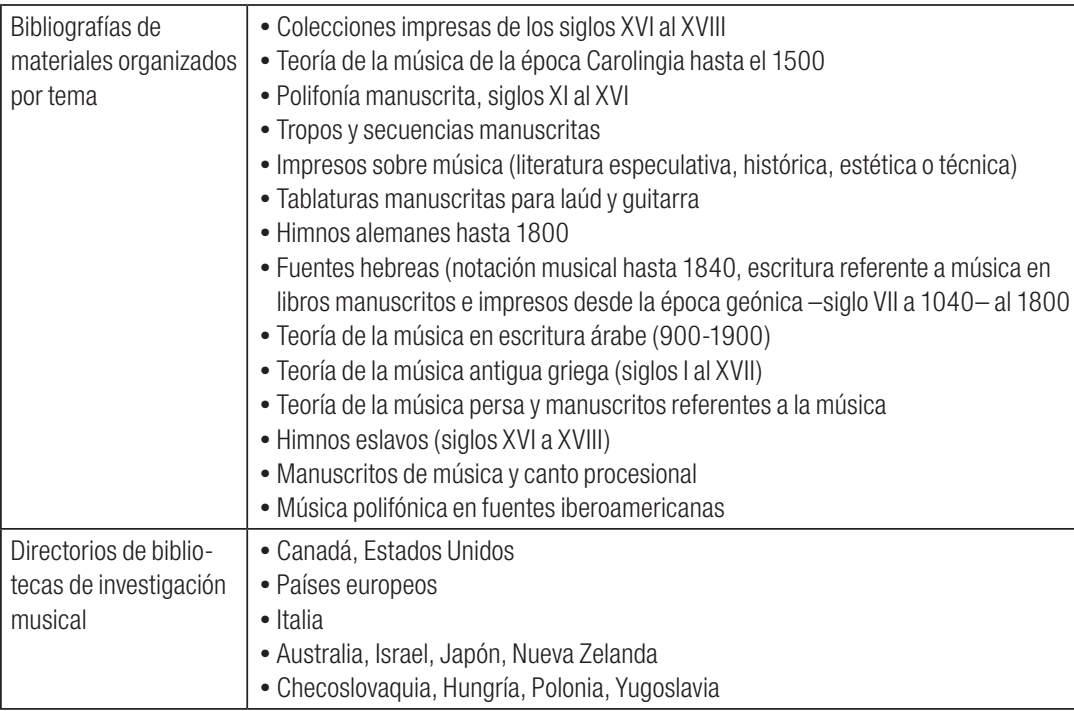

La iconografía es una disciplina auxiliar para el estudio de la historia de la música, de las prácticas interpretativas pasadas, su contexto social y cultural, la construcción de instrumentos musicales, la danza, ópera y el teatro; es apoyo para la historia general del arte y la literatura, la arqueología, la teología y los estudios culturales. Entre los proyectos más importantes, el Répertoire International d'Iconographie Musicale (RIdIM) ${ }^{11}$ se ocupa desde 1971 de la clasificación, catalogación y estudio de fuentes iconográficas relacionadas con la música. El RIdIM cuenta con el patrocinio de la IAML, la IMS y el International Committee of Musical Instrument Museum Collections (CIMCIM) del International Council of Museums (ICOM), vinculado con el RISM y el RILM. Esta red de trabajo pretende apoyar académica y profesionalmente a intérpretes, historiadores, bibliotecarios y lauderos y a productores escénicos, de libros y grabaciones. Para la difusión de su trabajo el RIdIM publica anualmente desde 1984 Imago Musicae de Librería Musicale Italiana y desde 2005 el RIdIM Newsletter. Los tipos de objetos con material iconográfico relacionado con la música destacados por el RIdIM (2015) son los siguientes (Tabla 5): de la Universidad de Londres. 
Tabla 5. Tipos de objetos con iconografía musical identificados por el Répertoire International d'Iconographie Musicale (RIdIM)

\begin{tabular}{|l|l|l|}
\hline Artes decorativas & Collage & Dibujos \\
\hline Escultura & Impresos & Instrumentos u objetos musicales \\
\hline Joyería & Juguetes & Libros \\
\hline Manuscritos, códices, rollos, pergaminos & Marcas de agua & Miniaturas \\
\hline Mobiliario & Mosaicos & Murales \\
\hline Numismática & Objetos fotográficos & Pinturas \\
\hline Textiles, vestuario & Vasijas & Objetos arquitectónicos \\
\hline
\end{tabular}

Existe una gran cantidad de documentos musicales - partituras, tablaturas- manuscritos e incunables difundidos mediante facsímiles en ediciones de música y de arte; muchos ejemplos de iconografía musical son facsímiles. Los facsímiles permiten el estudio de autores y obras desde las fuentes primarias. Existen empresas especializadas en la clasificación, catalogación y descripción de facsímiles de documentos musicales desde medievales hasta contemporáneos, con catálogos de música y de arte con citas bibliográficas y descripciones, incluso de libros raros y agotados, organizados por compositor, instrumentos, género, de fuentes compuestas y misceláneas, biblioteca de origen, selección de ediciones modernas y selección de monografías, memorias y revista, con frecuencia asociadas con los principales editores de facsímiles (OMI, s.f.) (Tabla 6).

Tabla 6. Editoriales de facsímiles musicales

\begin{tabular}{|l|l|l|}
\hline \multicolumn{1}{|c|}{ Editora } & \multicolumn{1}{c|}{ Ciudad } & \multicolumn{1}{c|}{ País } \\
\hline Akademische Druck- und Verlagsanstalt & Graz & Austria \\
\hline Alamire Publishers & Neerpelt & Bélgica \\
\hline Arnaldo Forni Editore & Bolonia & Italia \\
\hline Bärenreiter Facsimile Editions & Kassel & Alemania \\
\hline Beethoven-Haus Facsimile Editions & Bonn & Alemania \\
\hline $\begin{array}{l}\text { Boethius-Severinus Press, Scolar Press, } \\
\text { The English Lute Society }\end{array}$ & Guilford & Inglaterra \\
\hline Broude Brothers & New York & Estados Unidos \\
\hline Cornetto Verlag & Stuttgart, Baden-Wuntemberg & Alemania \\
\hline Éditions J.M. Fuzeau & Courlay & Francia \\
\hline Éditions Minkof & Ginebra & Suiza \\
\hline G. Henle Verlang Music Facsimiles & Munich & Alemania \\
\hline $\begin{array}{l}\text { Georg Olms Verlag, Hildesheim Facsimile } \\
\text { Reprints }\end{array}$ & Leipzig & Alemania \\
\hline Institute of Mediaeval Music & & Canadá \\
\hline Laaber Verlag Facsimile Editions & Ottawa & Alemania \\
\hline LIM-Libreria Musicale Italiana & Laaber, Ragensberg, Bavaria & \\
\hline
\end{tabular}




\begin{tabular}{|l|l|l|}
\hline OMI Old Manuscripts \& Incunabula & New York & Estados Unidos \\
\hline $\begin{array}{l}\text { Paléographie Musicale Facsimiles (L'Abbaye de } \\
\text { Saint-Pierre de Solesmes) }\end{array}$ & Solesmes, Sarthe & Francia \\
\hline $\begin{array}{l}\text { Paul Sacher Stiftung - Paul Sacher Foundation } \\
\text { Facsimile Editions }\end{array}$ & Basilea & Suiza \\
\hline Ricordi Facsimile Editions & Milán & Italia \\
\hline SPES-Studio per Edizioni Scelte & Florencia & Italia \\
\hline
\end{tabular}

Otros organismos especializados en el estudio documental de la música son los siguientes:

- ISMIR. International Symposium on Music Information Retrieval

- IMC. International Music Council

- ICTM. Internacional Council for Tradicional Music (Consejo Internacional para la Música Tradicional)

- ICM. International Council of Music (Consejo Internacional de Música, CIM)

- EUDOM. Euskalerriko Musika Liburutegein Elkartea (Asociación Vasca de Documentación Musical)

- CIM. Consejo Internacional de la Música (ICM)

- CEAA. Centro de Estudios de Archivos Audiovisuales

- CCAAA. Consejo de coordinación de las asociaciones de archivos audiovisuales

- ACIM. Association pour la coopération des professionnels de l'information musicale

\section{EL UNIVERSO DE LOS DOCUMENTOS SOBRE MÚSICA}

Si los acervos de partituras son todo un universo documental, los documentos sobre música, por cantidad y variedad, son un ámbito colosal. Para la bibliotecología los documentos librarios relacionados con la música son una amplia variedad de materiales cuyo contenido da noticia de la creación, interpretación y pensamiento, la teoría y la práctica musical, en aspectos de enseñanza, investigación, difusión y reflexión musicales; además dan cuenta de personas, obras, instrumentos, instituciones y procesos pasados y presentes del mundo de la música (Apéndice 2). Valiosa información adicional también se halla en la biblioteca de complemento, cuyos contenidos, aun sin relacionarse directamente con la música, aportan conocimiento valioso.

Para los documentos con literatura sobre música se cuenta con el Répertoire International de Littérature Musicale (RILM) surgido en 1964, hoy con 
sede en New York, producto de la colaboración de redes de musicólogos y bibliotecólogos en comités de 60 países (entre ellos México) quienes trabajan publicaciones sobre música. Así se conforma una bibliografía con citas, resúmenes e índices de publicaciones sobre diversos géneros y tipos de música de 174 países en 171 idiomas, con acceso a 800000 entradas.

El RILM incluye en sus repertorios artículos, colecciones de ensayos, facsímiles y reediciones, monografías, publicaciones periódicas, memorias de congresos, transcripciones, registros sonoros y de imagen en movimiento, notas a programas, grabaciones, ediciones y comentarios, disertaciones y tesis de grado, diagramas y planos de instrumentos musicales, recursos electrónicos (Tabla 7):

Tabla 7. Superclases de los documentos incluidos en el RILM

\begin{tabular}{|l|l|}
\hline Antologías & Arte musical occidental \\
\hline Arte musical occidental & Jazz y blues \\
\hline Literatura imaginativa & Materiales de referencia e investigación \\
\hline Música en liturgia y ritual & Música popular \\
\hline $\begin{array}{l}\text { Música tradicional y arte } \\
\text { musical no occidental }\end{array}$ & Música y disciplinas relacionadas \\
\hline Música y otras artes & Pedagogía \\
\hline Perspectivas universales & Práctica interpretativa y notación \\
\hline Registros sonoros & Teoría, análisis y composición \\
\hline
\end{tabular}

Complementan la difusión del trabajo del RILM publicaciones impresas con información a partir del segundo tercio del siglo XIX, las series RILM Retrospective con bibliografías de actualidad, RILM Perspectives (series) con memorias de conferencias patrocinadas por el RILM y RILM Abstracts of Music Literature (RILM, 2015).

\section{LOS ARCHIVOS PERSONALES Y PRIVADOS}

Lo musical también se plasma en carteles y anuncios, programas de mano y de temporada, críticas hemerográficas, radiofónicas o televisivas, catálogos de instrumentos y partituras, correspondencia personal, oficial y fiscal, fotografías, ediciones musicales, documentos administrativos, álbumes de presentaciones y estrenos, documentación institucional, empresarial, familiar y personal, que informan

el lugar del estreno, el ámbito en que éste se ha producido (festivales, homenajes, temporadas, ciclos, etc.), la existencia de un encargo por parte de alguna perso- 
na o entidad y los intérpretes que se hacen cargo de ese estreno, [datos] sobre sucesivas interpretaciones de la obra, [y referencias sobre] la difusión de la obra a través de los medios de comunicación [...], los nombres de los medios y de los programas, así como la fecha y hora de emisión, [y aún más, reseñas de] ediciones impresas y las grabaciones discográficas y videográficas existentes en el mercado, con mención de las compañías, las fechas y cuantos datos suelen aparecer en este tipo de productos. (Prieto Guijarro, 2011: 12-13)

La variedad de elementos documentales de un archivo personal, como notas, referencias a una obra, a la trayectoria o a los intereses particulares del propietario, trabajos para exposición, docencia o edición, programas de estudio, compilaciones temáticas, contratos e inventarios, etc., ofrecen detalles sobre personajes, su obra y pensamiento, las instituciones y su contexto, hechos políticos, culturales, sociales. Otros materiales gráficos de estos archivos pueden ser originales y reproducciones de arte bidimensionales, diagramas, fotografías, dibujos técnicos, proyectables, artefactos tridimensionales como modelos, casetes, escritura braille, esculturas y otras obras de arte, exhibiciones, máquinas y vestuario.

\section{MÚSICA EN LOS LIBROS SOBRE LIBROS}

En un estudio sobre fuentes documentales relacionadas con la música es imprescindible incluir los libros sobre libros: repertorios y catálogos que, para el interés de la musicología, se encuentran en las siguientes variedades (Pedraza García, 2004: 103-122) (Tabla 8):

Tabla 8. Libros sobre libros

\begin{tabular}{|c|c|c|}
\hline Repertorios bibliográficos & \multicolumn{2}{|c|}{$\begin{array}{l}\text { - Bibliografías generales de incunables e impresos antiguos. } \\
\text { - Tipobibliografías nacionales } \\
\text { - Biobibliografías } \\
\text { - Topobibliografías } \\
\text { - Bibliografías especializadas } \\
\text { - Recopilaciones de repertorios } \\
\end{array}$} \\
\hline \multirow[t]{3}{*}{ Catálogos } & - Catálogos colectivos & $\begin{array}{l}\text { - Catálogos colectivos de incu- } \\
\text { nables }\end{array}$ \\
\hline & - Catálogos de bibliotecas & $\begin{array}{l}\text { - Catálogos de manuscritos } \\
\text { - Catálogos de incunables } \\
\text { - Catálogos de libros por periodos }\end{array}$ \\
\hline & \multicolumn{2}{|c|}{ - Catálogos de bibliotecas de bibliófilo } \\
\hline \multicolumn{3}{|c|}{ Repertorios para libreros y bibliófilos } \\
\hline \multicolumn{3}{|c|}{ Catálogos de librerías anticuarias y de subastas } \\
\hline \multicolumn{3}{|c|}{\begin{tabular}{|l|} 
Catálogos comerciales impresos y en línea \\
\end{tabular}} \\
\hline
\end{tabular}


Otros catálogos con información sobre materias de interés musical se muestran en la Tabla 9 (Escalada, 2009: 2; Iglesias Martínez y Lozano, 2008: 415-418).

Tabla 9. Catálogos con información de interés musical

\begin{tabular}{|l|l|}
\hline$\bullet$ Géneros musicales & $\begin{array}{l}\bullet \text { Editoriales de música publicada impresa y } \\
\text { digital }\end{array}$ \\
\hline - Registros sonoros & $\bullet$ Editores \\
\hline - Instrumentos & $\bullet$ Libretos y argumentos \\
\hline $\begin{array}{l}\text { - Directorios de orquestas } \\
\text { sinfónicas }\end{array}$ & $\bullet$ Agendas artísticas \\
\hline - Cancioneros & $\bullet$ Discografías \\
\hline
\end{tabular}

\section{Publicaciones PERIÓdicas y SERIADAS}

Las publicaciones periódicas y seriadas tanto impresas como digitales (y en línea) tienen un proceso de producción más ágil que el del libro, pues sus contenidos, divididos en capítulos, artículos o secciones, generalmente de distintos autores, ofrecen avances de investigaciones, noticias, reseñas, disertaciones y memorias que constituyen un excelente medio de difusión actualizada. Estas publicaciones seriadas y periódicas, de interés por sí mismas y como obras de referencia, incluyen periódicos o diarios, anuarios, revistas, memorias, actas, etc., así como series monográficas numeradas. Comúnmente ostentan títulos como anuario, boletín, circular, informe, información, noticias, papeles, revista.

El Répertoire International de la Presse Musicale (RIPM), fundado en 1980, es una asociación en la que colaboran académicos, musicólogos, bibliotecarios y archivistas de 20 países; se encarga de la indexación de literatura y publicaciones periódicas relacionadas con la música producidas de fines del siglo XVIII a mediados del XX, entre ellas revistas musicales, de teatro, de modas, de musicología, grabados y litografía en la prensa ilustrada, folletines, periódicos, artículos en revistas de literatura. El resultado de su labor es una importante fuente para el estudio detallado de la historia de la música y la actividad musical desde la perspectiva de sus contemporáneos y de la musicología.

El índice retrospectivo del RIPM comprende 223 publicaciones periódicas de 1760 a 1966 indexadas y está disponible tanto impreso (312 volúmenes 1988-2015) como en línea (desde 2009). Actualmente registra 739000 entradas y se actualiza semestralmente. El RIPM cuenta con el auspicio de la 
IMS, la IAML y la ICPSH ${ }^{12}$ de la Unesco y, desde 2006, de México a través del Centro Nacional de Investigación y Documentación e Información Musical "Carlos Chávez" (CENIDIM). Las publicaciones periódicas mexicanas incluidas en el RIPM se muestran en la Tabla 10 (RIPM, 2015).

Tabla 10. Publicaciones periodicas mexicanas en el Répertoire International de la Presse Musicale (RIPM)

\begin{tabular}{|l|l|}
\hline \multicolumn{1}{|c|}{ Publicadas } & \multicolumn{1}{c|}{ Próximamente } \\
\hline Armonía (1866-1867) & \\
\hline La Batuta (1874) & El sonido 13 (1924-1928) \\
\hline Gaceta Musical (1928-1929) & Revista Musical Mexicana (1942-1946) \\
\hline Música: Revista Mexicana (1930-1931) & Nuestra Música (1946-1953) \\
\hline Cultura Musical (1936-1937) & \\
\hline
\end{tabular}

\section{CONFORMACIÓN DE LAS COLECCIONES MUSICALES}

Las obras de una colección musical pueden incluir especificaciones como repertorio de intérprete individual, de agrupación musical, colección de obras de un compositor, biblioteca de coleccionista particular, archivos y bibliotecas de entidades desaparecidas. Se distinguen tres tipos de catálogos: a) literatura musicológica, destinada a especialistas, musicólogos y estudiantes; b) obras de referencia, diccionarios, catálogos y enciclopedias, guías y anuarios, y c) obras destinadas al gran público como reediciones en colecciones de títulos de comprobada aceptación y nuevas ediciones de títulos de divulgación musical.

Las colecciones se conforman con fondos procedentes de compra, donaciones, o convenios de comodato y custodia y de decisiones políticas. Entre estas últimas resaltan las leyes de desamortización del siglo XIX, que incluyeron códices y obras musicales empleadas en las ceremonias litúrgicas, ordinarios y festividades en catedrales, conventos, monasterios e iglesias. La Ley de nacionalización de bienes eclesiásticos de México (1859) no desglosa contenidos ni temáticas de los libros y documentos nacionalizados, sólo menciona su ingreso al "tesoro de la nación", de forma que los libros, impresos y manuscritos y demás objetos de las comunidades religiosas suprimidas se destinaron a museos, liceos, bibliotecas y otros reservorios.

12 IMS. International Musicological Society; IAML. International Association of Music Libraryes Archives and Documentation Centres; ICPSH. International Council for Philosophy and Humanistic Studies. 
Una importante cantidad de colecciones debe su integración y difusión a acciones de rescate, redescubrimiento y recuperación de fondos olvidados o perdidos, muchos de ellos rescatados de rincones abandonados en instituciones públicas, religiosas, educativas y archivos personales, generalmente en pobres condiciones de conservación que requieren una impostergable y especializada intervención para evitar su pérdida definitiva. Otra modalidad de adquisición de fondos son las leyes de depósito legal, que obligan al editor y al autor a entregar, generalmente a bibliotecas nacionales, un ejemplar de la obra publicada; lamentablemente hay grandes vacíos en la normatividad que se acentúan cuando de documentos sonoros y audiovisuales se trata.

\section{Colofón}

En el estudio de la música, actividad intrínsecamente sonora y efímera, no todo es sonoro y fugaz: existen evidencias silenciosas que dan testimonio permanente de su existencia y de la percepción que de ésta se tiene y se ha tenido en diferentes épocas y latitudes. Esos testigos silentes son las partituras, los textos, los tratados y una gran variedad de documentos. El mundo del libro de música y de lo relacionado con ella no es un libro raro, sino una especial e inagotable fuente de indagación para la musicología tanto en su contenido como en su soporte, por su valor documental y patrimonial. Los documentos musicales dan cuenta de lo cotidiano y de lo extraordinario, son memoria histórica de la creación y la innovación, de la interpretación y la producción, la publicación, la distribución y la aprehensión de la música.

Cada libro va adquiriendo un perfil propio a lo largo de su existencia y presenta un valor particular ante las miradas del bibliotecólogo, del investigador, del docente o del intérprete, por ello su aprecio y tratamiento tienen diferentes facetas. Puede ser tratado como un producto histórico, bibliográfico, textual, tipográfico, editorial, de la actividad estética, de las expresiones culturales. Los acervos musicales son un universo que debe ser abordado desde diferentes perspectivas, especialidades, funciones y objetivos. El tratamiento, gestión, estudio y difusión de los fondos musicales requiere de profesionales en la documentación y la información, así como de musicólogos, intérpretes, historiadores, paleógrafos musicales y diplomatistas, con una visión actual y un enfoque transdisciplinario que los sitúe en el contexto social global con alcances culturales, e incluso económicos y medioambientales. 


\section{BIBLIOGRAFÍA Y FUENTES DE INFORMACIÓN}

Arévalo, Víctor Hugo. 1991. Diccionario de términos archivísticos. Asociación de Archiveros de Santa Fe. Fecha de consulta: 14 de julio de 2014, http://www.mundoarchivistico.com/?menu=diccionario

Arizpe, L., ed. 2001. Informe Mundial sobre Cultura 2000-2001. Diversidad cultural, conflicto y pluralismo. España: Unesco/Mundi-Prensa.

Baker, T., N. Slominsky y L. Kuhn, eds. 1995. Schirmer pronouncing pocket manual of musical terms. New York: Schirmer Trade Books.

Bañuelas, R. 2009. Diccionario del cantante. Terminología clásica, vocal, musical y cultural. México: Trillas.

Brenne, Marte. 2004. Storage and retrieval of musical documents in a FRBR-based library catalogue - a comparison with the traditional databases in libraries today. Oslo: Master thesis Oslo University College Faculty of journalism, library and information science.

Burgos Bordonau, E. y C. Petrescu. 2011. "Typology of the musical document: an approach to its study". Bulletin of the Transilvania University of Brasov. Series VIII. 4 (53) (2): 31-38. Fecha de consulta: 14 de julio de 2014, http://pendientedemigracion.ucm.es/centros/cont/descargas/documento39570.pdf

Cabezas Bolaños, Esteban. 2005. "La organización de archivos musicales. Marco conceptual”. Información, Cultura y Sociedad (Universidad de Buenos Aires. Instituto de Investigaciones Bibliotecológicas) 13: 81-99. Fecha de consulta: 18 de septiembre de 2013, http://www.scielo.org.ar/pdf/ics/n13/n13a05.pdf

Clemente San Román, Yolanda. 2003. "Análisis, identificación y descripción analítica del libro antiguo. Las ediciones y sus variantes: emisiones y estados". En El libro antiguo, Manuel José Pedraza, Yolanda Clemente y Fermín de los Reyes, 249-266. Madrid: Síntesis: biblioteconomía y documentación.

Conacyt. S. f. Manual. Curriculum Vitae Único. México: Presidencia de la Repúblic, Conacyt.

COTENNDOC. 2008. Norma Mexicana de Catalogación de documentos fonográficos NMX-R-002-SCFI-2007, editada por el Comité Técnico de Normalización Nacional de Documentación. México: ILCE.

Dirección General del Libro. 1999. Reglas de Catalogación. Edición nuevamente revisada. Madrid: Ministerio de Educación y Cultura, Centro de Publicaciones, Boletín Oficial del Estado.

Escalada, Estela. 2009. "Particularidades en la descripción de partituras de la Biblioteca Nacional”. Experiencias en la organización y tratamiento de la información en las bibliotecas argentinas, vol. I, 227-242. Fecha de consulta: 14 de julio de 2014, www.bn.gov.ar/ descargas/catalogadores/ponencia_escalada.pdf 
EUDOM (Asociación Vasca de Documentación Musical). 2007. Musikako liburuen, partituren eta soinu-grabazioen sailkapen sistematikoa [Clasificación sistemática de libros de música, partituras y grabaciones sonoras]. País Vasco, Vitoria-Gasteiz: Eusko Jaurlaritzaren Argitalpen Zerbitzu Nagusia [Servicio Central de Publicaciones del Gobierno Vasco]. (Bibliotekonomia, Colección Bilduma).

Glosario de términos bibliotecarios RDIB. S. f. http://www.bibliopos.es/ recursos/enlaces/recursos-bibliotecarios1.htm\#10 y http://www. rdib.net/glosario.htm\#b (fecha de consulta: 28 de febrero de 2012).

Gorman, Michael y Paul Walter Winkler. 1999. Reglas de Catalogación Angloamericanas (AACR2). Preparadas bajo la dirección del Joint Steering Committee for Revision of AACR, un comité de la American Library Association et al. Traducido por Margarita Amaya de Heredia. Santa Fé de Bogotá: LTDA.

GTCCPB. 2010. Manual de música notada. Consejo de Cooperación Bibliotecaria Grupo de Trabajo de Catálogo Colectivo del Patrimonio Bibliográfico. Fecha de consulta: 14 de julio de 2014, http:// travesia.mcu.es/portalnb/jspui/bitstream/10421/6041/1/MusicaMARC-jun2010conM.pdf

Hitchcock, H. Wiley y James Deaville. S. f. Musicology. Grove Music Online. Oxford Music Online. Oxford University Press. Fecha de consulta: 1 de mayo de 2015, http://www.oxfordmusiconline.com/ subscriber/article/grove/music/A2242442

Iglesias Martínez, Nieves e Isabel Lozano. 2008. La música del siglo XIX. Una herramienta para su descripción bibliográfica. Madrid: Biblioteca Nacional de España. Ministerio de Cultura.

Lawson, C. 2011. "La interpretación a través de la historia", en La interpretación musical, J. Rink, 19-34. Madrid: Alianza Música.

McCleary, J. 1997. Glosario de términos técnicos de conservación de libros y documentos. Inglés-español, español-inglés. Madrid: Clan.

Moliner, M. 2002. Diccionario de uso del español, 2a. ed. Madrid: Gredos.

OMI (Old Manuscripts \& Incunabula). S. f. Fecha de consulta: 4 de mayo de 2015, http://www.omifacsimiles.com/index.html

Pedraza García, Manuel José. 2004. "El libro antiguo: concepto y estructura". En Precio y valor del libro antiguo (Textos y materiales), Jaca, 2-6 de septiembre, coord. por Manuel José Pedraza García, 11-48. Zaragoza: Prensas Universitarias de Zaragoza.

Prieto Guijarro, Laura. 2011. "Los legados musicales. Metodología de valorización: el legado musical de Juan José Mantecón”. Ponencia presentada en las Quintas Jornadas de Archivo y Memoria. Extraordinarios y fuera de serie: formación, conservación y gestión de archivos personales, Madrid, 17-18 de febrero.

Reyes Gómez, Fermín de los. 2003. "El concepto de libro antiguo”. En El libro antiguo, Manuel José Pedraza, Yolanda Clamente y Fermín de los Reyes, 11-44. Madrid: Síntesis: biblioteconomía y documentación. 
RIdIM (Répertoire International d'Iconographie Musicales). 2015. Zurich. Fecha de consulta: 4 de mayo de 2015, http://www.ridim. org/

RILM (Répertoire International de Littérature Musicale). 2015. The Graduate Center, City University of New York. 2015. Fecha de consulta: 9 de mayo de 2015, http://www.rilm.org/

RIPM (Répertoire International de la Presse Musicale). 2015. Center for Studies in Nineteenth Century Music of the University of Maryland. Fecha de consulta: 9 de mayo de 2015, http://www. ripm.org/index.php

RISM (Répertoire International des Sources Musicales). 2015. Fecha de consulta: 9 de mayo de 2015, http://www.rism.info/en/home. html

Rodríguez Bravo, Blanca. 2002. "Revisión de las clasificaciones documentales basadas en el soporte". Revista española de Documentación Científica 25 (1) (enero): 74-86. DOI: 10.3989/redc.2002.v25. i1.87

Sánchez Mariana, Manuel. 1995. Introducción al libro manuscrito. Madrid: Editorial Arco Libros. (Instrumenta Bibliologica.)

Smiraglia, Richard P. 2001. "Musical Works as Information Retrieval Entities: Epistemological Perspectives". Second International Symposium on Musica Information Retrieval. Bloomington: ISMIR.

Tacón Clavaín, Javier. 2004. "La conservación del libro antiguo". Documentos de trabajo UCM Biblioteca Histórica 2: 1-14.

Torres Mulas, Jacinto. 2000. "El documento musical: ensayo de tipología”. Cuadernos de documentación multimedia 10 (Ejemplar dedicado a I Congreso Universitario de Ciencias de la Documentación. Teoría, historia y métodología de la documentación en España (1975-2000)): 743-748. Fecha de consulta: 18 de febrero de 2013, http:/www.ucm.es/info/multidoc/multidoc/revista/num10 /paginas/pdfs/Jtorres.pdf

Unesco, 1948. Acuerdo destinado a facilitar la Circulación Internacional de Materiales Audiovisuales de Carácter Educativo, Cientifico y Cultural. Conferencia General Beirut.

Unesco. 1980. Recomendación sobre la salvaguardia y la conservación de las imágenes en movimiento. Conferencia General, Belgrado.

WCCD. 1996. Nuestra Diversidad Creativa. Informe de la Comisión Mundial de Cultura y Desarrollo, Javier Pérez de Cuéllar (coord.), A. N. García (ed.). México: UNESCO, Correo de la UNESCO México. 
Apéndice 1

Tipología de partituras por su catalogación y tratamiento bibliográfico

\begin{tabular}{|c|c|c|c|c|}
\hline AACR2 & $\begin{array}{l}\text { El documento } \\
\text { música: ensayo } \\
\text { de tipología }\end{array}$ & $\begin{array}{c}\text { Aproximación al } \\
\text { estudio de la } \\
\text { tipología del } \\
\text { documento musical }\end{array}$ & $\begin{array}{c}\text { Una herramienta } \\
\text { para su descripción } \\
\text { bibliográfica }\end{array}$ & $\begin{array}{c}\text { Manual de música } \\
\text { notada }\end{array}$ \\
\hline & Borrador 0 apunte ${ }^{1}$ & & & \\
\hline $\begin{array}{l}\text { Partitura (completa } \\
=\text { full score) }\end{array}$ & Partitura & Partitura (score) & $\begin{array}{l}\text { Partitura (de direc- } \\
\text { tor) + partes (para } \\
\text { cada intérprete) }\end{array}$ & $\begin{array}{l}\text { Partitura de } \\
\text { orquesta }\end{array}$ \\
\hline \multirow[t]{3}{*}{ Parte $^{2}$} & Parte o particella & $\begin{array}{l}\text { Parte o particella } \\
\text { (part) }\end{array}$ & Parte(s) & \\
\hline & Reducciones: & & & \\
\hline & Guión ${ }^{3}$ & & Guión & \\
\hline $\begin{array}{l}\text { Parte de piano } \\
\text { [violín, etc.] del } \\
\text { director }{ }^{4}\end{array}$ & $\begin{array}{l}\text { Parte de } \\
\text { [instrumento] } \\
\text {-director }\end{array}$ & $\begin{array}{l}\text { Parte de piano-di- } \\
\text { rector, violín-direc- } \\
\text { tor, etc. }\end{array}$ & $\begin{array}{l}\text { Parte de piano (vio- } \\
\text { lín, etc.) director }\end{array}$ & $\begin{array}{l}\text { Partitura reducida } \\
\text { para director de } \\
\text { orquesta o piano }\end{array}$ \\
\hline Partitura vocal & Partitura vocal & Partitura vocal & Partitura vocal & Partitura vocal \\
\hline $\begin{array}{l}\text { Partitura para } \\
\text { piano }^{5}\end{array}$ & $\begin{array}{l}\text { Reducción para } \\
\text { teclado }\end{array}$ & $\begin{array}{l}\text { Reducción a piano } \\
\text { (piano reduction) }\end{array}$ & $\begin{array}{l}\text { Reducción para } \\
\text { piano }\end{array}$ & $\begin{array}{l}\text { Acompañamiento } \\
\text { /Reducción para } \\
\text { teclado }\end{array}$ \\
\hline Partitura abreviada ${ }^{6}$ & Partitura abreviada & Partitura abreviada & Partitura abreviada & \\
\hline Partitura coral & & Partitura coral & Partitura de coro & \\
\hline
\end{tabular}

1 Borrador, apunte (short score). Esbozo hecho por un compositor para una obra, en el que presenta en pocos pentagramas las características principales de la composición.

2 Parte (parte (music)) o particella. Música para una de las voces o instrumentos de una obra musical (AACR2) (Gorman y Winkler, 1999: 692). Cada una de las hojas sueltas de música destinadas a una voz o a un instrumento en una ejecución de un conjunto. También denominada particella (GTCCPB, 2010: 145).

3 Guión, resumen de una partitura, solo con la parte principal en 2 a 5 pentagramas, por secciones instrumentales. Cada pentagrama incluye instrumentos de parecidas tesituras. Típico de la música de banda y orquesta. Formato que debe reflejarse en el subencabezamiento de materia (Iglesias Martínez y Lozano, 2008: 220; GTCCPB, 2010: 145).

4 Parte de [instrumento] del director. Parte de interpretación a la que se añaden anotaciones de entradas de los distintos instrumentos para facilitar al intérprete su papel también como director; a veces llamada "partitura de piano (violín, etc.) director". Es habitual que venga acompañada de las partes instrumentales independientes (Iglesias Martínez y Lozano, 2008: 224). En una obra para un conjunto, la parte de un instrumento que permite al intérprete dirigirlo ayudado de anotaciones de las entradas de los otros instrumentos (GTCCPB, 2010: 146). Parte para la ejecución de un instrumento de una obra en conjunto, a la que se agregan las entradas para los otros instrumentos, para permitirle dirigir también la ejecución de la obra (AACR2) (Gorman y Winkler, 1999: 62).

5 Parte para piano (piano score) o reducción para teclado. Reducción de una partitura orquestal a una versión para piano, en dos pentagramas (AACR2) (Gorman y Winkler, 1999: 693). Las obras originalmente compuestas para orquesta u otro conjunto instrumental que se han arreglado para piano (Iglesias Martínez y Lozano, 2008: 225).

6 Partitura abreviada (condensed score). Registra solamente las partes musicales principales en un número mínimo de pentagramas, generalmente organizados por secciones instrumentales (AACR2) (Gorman y Winkler, 1999: 692). 


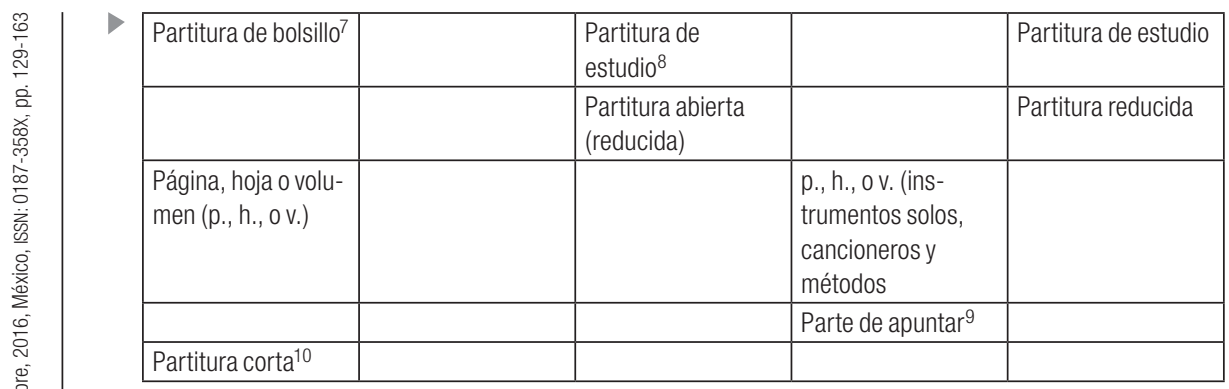

7 Partitura de bolsillo. Partituras reducidas en tamaño y que no están destinadas principalmente para ejecución (AACR2) (Gorman y Winkler, 1999: 165).

8 Partitura de estudio. Partitura completa cuyo fin es el estudio y no la interpretación. Se utiliza la misma denominación para partitura de bolsillo o miniatura (Dirección General del Libro, 1999: 590).

9 Parte de apuntar. Formato característico de la zarzuela, y es lo mismo que la partitura vocal, pero las partes instrumentales no tienen por qué estar necesariamente reducidas para piano; pueden estarlo para cualquier instrumento de registro bajo. Es un formato en el que, a veces, se indican las entradas de otros instrumentos (GTCCPB, 2010: 145; Iglesias Martínez y Lozano, 2008: 210).

10 Partitura corta (close score). Registra todas las partes en un número mínimo de pentagramas, normalmente dos, como en los himnos (AACR2) (Gorman y Winkler, 1999: 692). 


\section{Apéndice 2}

Descripciones de los tipos documentales relacionados con la música*

\begin{tabular}{|c|c|c|}
\hline \multirow{10}{*}{$\begin{array}{l}\frac{\pi}{0} \\
\frac{0}{0} \\
\frac{0}{0} \\
\frac{0}{0} \\
\frac{0}{0} \\
\frac{\pi}{2} \\
0\end{array}$} & \multicolumn{2}{|c|}{ Enciclopedias y diccionarios } \\
\hline & \multicolumn{2}{|l|}{ Bibliografías } \\
\hline & \multicolumn{2}{|l|}{ Fonografías } \\
\hline & \multicolumn{2}{|l|}{ Musicografías } \\
\hline & \multicolumn{2}{|c|}{ Catálogos (catálogos completos de valor documental) } \\
\hline & \multicolumn{2}{|l|}{ Iconografías } \\
\hline & \multicolumn{2}{|c|}{ Índices y catálogos temáticos } \\
\hline & \multicolumn{2}{|c|}{ Repertorios musicales } \\
\hline & \multicolumn{2}{|c|}{ Escritos introductorios y generales sobre la música } \\
\hline & \multicolumn{2}{|c|}{ Obras de tratamiento de la documentación musical } \\
\hline \multirow{9}{*}{ 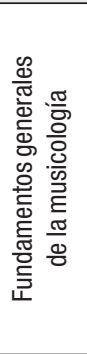 } & \multicolumn{2}{|c|}{ Exposiciones generales } \\
\hline & \multicolumn{2}{|c|}{ Fundamentos físicos y fisiológicos de la música } \\
\hline & \multicolumn{2}{|c|}{ Filosofía y psicología de la música } \\
\hline & \multicolumn{2}{|c|}{ Estilística-fundamentos del análisis } \\
\hline & \multicolumn{2}{|l|}{ Crítica musical } \\
\hline & \multicolumn{2}{|c|}{ Investigación musical } \\
\hline & \multicolumn{2}{|c|}{ Sociología de la música } \\
\hline & \multicolumn{2}{|c|}{ Antropología de la música } \\
\hline & \multicolumn{2}{|c|}{ Historia de la musicología } \\
\hline \multirow{2}{*}{ 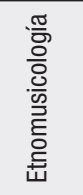 } & General & $\begin{array}{l}\text { General. El Mundo / Exposiciones generales / Etnología. Etnografía. Antro- } \\
\text { pología / Cancioneros musicales. Recopilaciones / Danzas / Organología / } \\
\text { Textos. Cancioneros literarios / Cuentos. Leyendas / Teatro musical popular } \\
\text { / Poesía oral / Tradiciones }\end{array}$ \\
\hline & Especial & Por regiones / Por continentes / Por países / Por comunidades \\
\hline \multirow{6}{*}{ 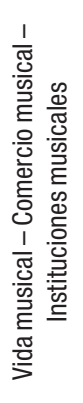 } & $\begin{array}{l}\text { Agrupaciones } \\
\text { musicales }\end{array}$ & $\begin{array}{l}\text { General / Orquestas / Bandas / Agrupaciones instrumentales populares / } \\
\text { Coros (orfeones, etc.) / Conjuntos instrumentales / Otros }\end{array}$ \\
\hline & $\begin{array}{l}\text { Instituciones de } \\
\text { música }\end{array}$ & $\begin{array}{l}\text { General / Organismos de la administración / Asociaciones profesionales } \\
\text { (sindicatos, etc.) / Asociaciones difusoras. Festivales / Teatros y salas / } \\
\text { Centros de enseñanza / Otros }\end{array}$ \\
\hline & \multicolumn{2}{|c|}{ Instituciones de documentación musical } \\
\hline & Comercio musical & $\begin{array}{l}\text { General / Editoriales musicales / Industria discográfica / Comercio musical: } \\
\text { instrumentos y accesorios musicales }\end{array}$ \\
\hline & \multicolumn{2}{|c|}{ Aspectos jurídicos de la vida musical } \\
\hline & Praxis musical & $\begin{array}{l}\text { Exposiciones generales / Vida musical. Cultura musical / La profesión / La } \\
\text { música y los medios de comunicación / Producción musical }\end{array}$ \\
\hline
\end{tabular}

* Basado en Musikako liburuen, partituren eta soinu-grabazioen sailkapen sistematikoa. Clasificación sistemática de libros de música, partituras y grabaciones sonoras. Bibliotekonomia, Colección Bilduma (EUDOM, 2007: 18-48). Se optó por esta fuente por ser la más detallada entre las consultadas. 


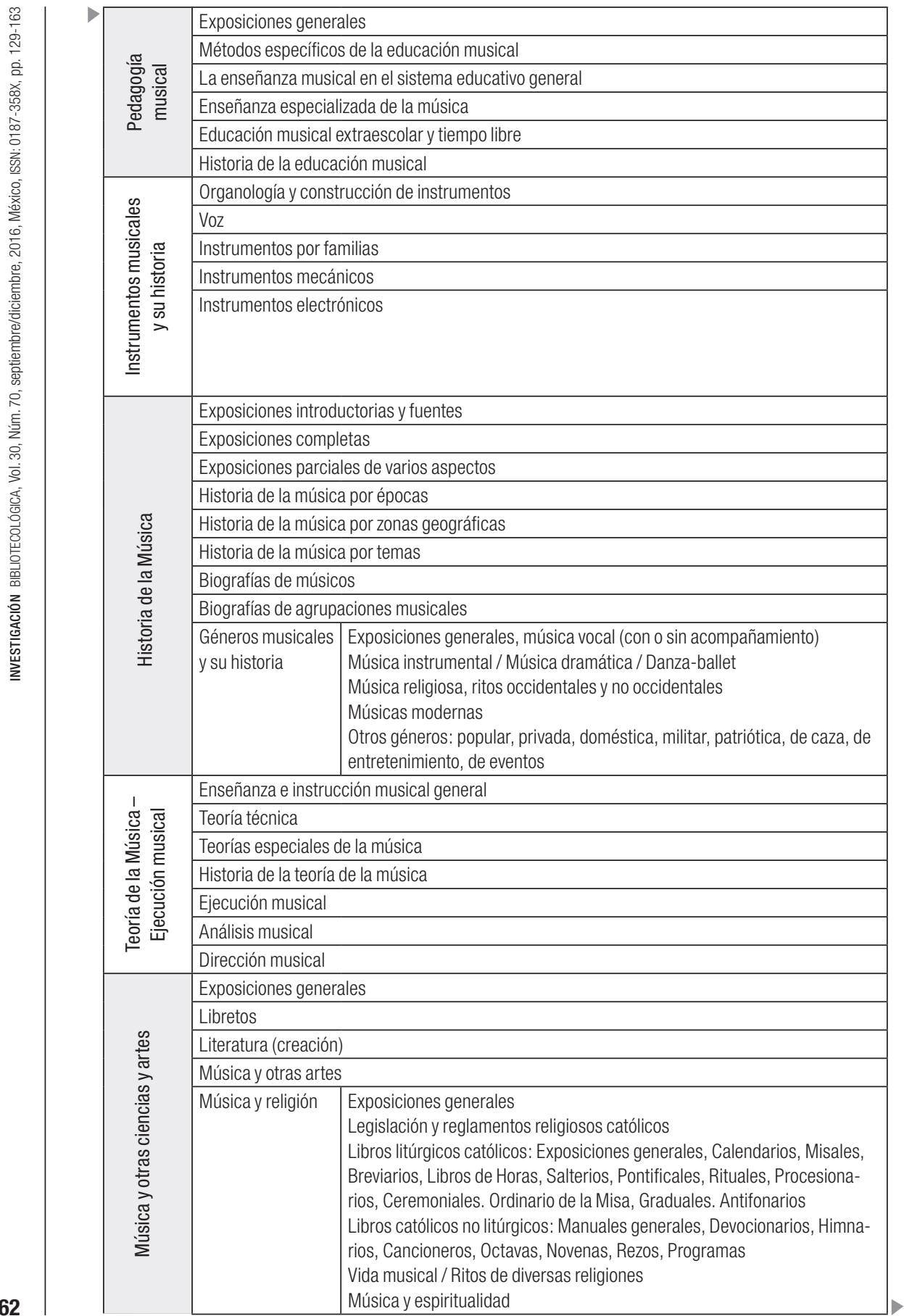




\begin{tabular}{|c|c|c|}
\hline \multirow[t]{5}{*}{$>$} & Música y medicina & $\begin{array}{l}\text { Exposiciones generales } \\
\text { Musicoterapia. Danzaterapia } \\
\text { Enfermedades profesionales } \\
\text { Educación y prevención (posturas, relajación...) } \\
\text { Otros aspectos médicos }\end{array}$ \\
\hline & $\begin{array}{l}\text { Música y tecno- } \\
\text { logía }\end{array}$ & $\begin{array}{l}\text { Exposiciones generales } \\
\text { Tratamiento del sonido: exposiciones generales, grabación y edición del } \\
\text { sonido } \\
\text { Informática musical: exposiciones generales, programas y software, } \\
\text { Equipos y hardware, Internet } \\
\text { MIDI } \\
\text { Otros estándares, formatos y soportes } \\
\text { Otros aspectos técnicos }\end{array}$ \\
\hline & $\begin{array}{l}\text { Música y otras } \\
\text { materias }\end{array}$ & $\begin{array}{l}\text { Exposiciones generales } \\
\text { Imprenta y publicidad. Tipografía } \\
\text { Música y política } \\
\text { Música y otras materias } \\
\end{array}$ \\
\hline & $\begin{array}{l}\text { Imágenes gráficas } \\
\text { musicales }\end{array}$ & $\begin{array}{l}\text { General / Pintura / Escultura / Gráfica (estampas y grabados) / Fotografías / } \\
\text { Comics / Otras técnicas }\end{array}$ \\
\hline & $\begin{array}{l}\text { Colecciones } \\
\text { especiales }\end{array}$ & $\begin{array}{l}\text { Láminas. Cuadros sinópticos } \\
\text { Varios }\end{array}$ \\
\hline
\end{tabular}

Para citar este artículo:

Reyes Gallegos, Artemisa M. 2016. "Los acervos de documentos musicales. ¿Libros raros, libros especiales?” Investigación Bibliotecológica: Archivonomía, Bibliotecología e Información 70: 129-163. http://dx.doi.org/10.1016/j.ibbai.2016.10.007 